\title{
ORGANIC COMPOUNDS IN ROOT EXUDATES OF Miscanthus $\times$ Giganteus GREEF ET DEU AND LIMITATION OF MICROORGANISMS IN ITS RHIZOSPHERE BY NUTRIENTS
}

\author{
H. Kaňová, J. Carre, V. Vranová, K. Rejšek, P. Formánek
}

Received: June 24, 2010

\begin{abstract}
KAŇOVÁ, H., CARRE, J., VRANOVÁ, V., REJŠEK, K., FORMÁNEK, P.: Organic compounds in root exudates of Miscanthus $\times$ Giganteus greef et deu and limitation of microorganisms in its rhizosphere by nutrients. Acta univ. agric. et silvic. Mendel. Brun., 2010, LVIII, No. 5, pp. 203-208
\end{abstract}

This study was conducted to determine the composition of sugars and organic acids in root exudates of Miscanthus $\times$ Giganteus and to find out if microorganisms of the rhizospheric soil are limited by mineral nutrients. The following sugars and organic acids were determined in root exudates of this plant: glucose, saccharose, and acids such as succinic, propionic, citric, tartaric, malic, oxalic, ascorbic, acetic and fumaric. Respiration of soil from rhizosphere of Miscanthus $\times$ Giganteus was found to be limited by $\mathrm{N}, \mathrm{K}$ and $\mathrm{Ca}$. Respiration rate after application of mineral compounds increased in following orther: nitrate $>$ calcium $>$ potassium $>$ ammonium, giving approx. 165, 99, 52 and 31\% increase compared to control. Further research is necessary to determine the role of plant nutrients from the point of their limitations for rhizosphere microorganisms, to broader very rare knowledges in this topic, especially for polluted soils to stimulate efficiency of phytoremediations.

root exudates, Miscanthus $\times$ Giganteus, organic acids, sugars, respiration, rhizosphere, soil, mineral nutrients

\begin{abstract}
Miscanthus $\times$ Giganteus Greef et Deu is a perennial, rhizomatous $\mathrm{C}_{4}$-grass originating from Southeast Asia. This species is sterile and probably natural hybrid involving $M . \times$ sacchariflorus (diploid) and M. sinensis (tetraploid) with a triploid chromosome, incapable of producing seeds (Greef and Deuter, 1993; Linde-Laursen, 1993). Its propagation is by micropropagation or by rhizome cutting. $M . \times$ Giganteus Greef et Deu was firstly identified in 1935 in Japan, from where it was introduced into Denmark, and it was named Miscanthus sinensis "Giganteus" hort. (Greef and Deuter, 1993; Greef et al., 1997). Canopy of $M . \times$ Giganteus can reach a height of $4 \mathrm{~m}$ and the estimated life time of a plantation is 20-25 years (Lewandowski et al., 2003a). M. × Giganteus belongs to group of Miscanthus species cultivated across Europe as a potential biofuel (Lewandowski et al., 2003b; Collura et al., 2006; Michel et al., 2006 etc.). This plant is also suitable for the production of raw material for the paper industry, composts, geotextiles, and in construction materials such as pressed parti-
\end{abstract}

cle-board and in manufacturing biocomposites etc. (Greef and Deuter, 1993; Stander, 1989; Huisman et al., 1997; Lewandowski et al., 2000; Kirwan et al., 2007; Marín et al., 2009). M. × Giganteus is promising for phytoremediation of heavy metals (Arduini et al., 2006; Hartley et al., 2009) and was suggested for landfill leachate remediation (Jones et al., 2006).

Up to $40 \%$ of the net carbon fixed during plant photosynthesis can be released into the rhizosphere (Whipps and Lynch, 1983, 1990). These rhizodeposits stimulate microbial growth due to their high energy and C content. The water-soluble fraction of rhizodeposits called water-soluble root exudates is mainly composed of sugars, organic acids and amino acids (Aulakh et al., 2001). Except for the determination of composition of amino acids in root exudates of Miscanthus × Giganteus (Formánek et al., 2009), there is no knowledge of organic acids and sugars relating to this plant. This study therefore identifies sugars and organic acids in root exudates of $M$. × Giganteus. 
Respiration of rhizosphere microorganisms is not limited by available carbon. Nevertheless, mineral nutrients may be limiting due to their depletion (Merckx et al., 1987; Cheng et al., 1996). As little is known of the limitation of rhizosphere microorganisms activity by mineral nutrients, we have attempted to determine this effect with the use of selected mineral compounds on respiration of soil from rhizosphere of Miscanthus $\times$ Giganteus. Soil from rhizosphere of an extensively studied plant Miscanthus $\times$ Giganteus was selected to broaden current knowledge related to this plant.

\section{MATERIAL AND METHODS}

Rhizomes of $M$. × Giganteus were taken from its cultivation in Botanic Gardens and Arboretum of Mendel University in Brno, the Czech Republic (N 49¹2'54.240", E 16³6'41.989", 235.19 meters a.s.l). The cultivation of this plant has been established over 15 years ago on a plot of $291.41 \mathrm{~m}^{2}$. Plant roots were sampled in two blocks. The first one during the period $27^{\text {th }}$ August to $5^{\text {th }}$ September when roots clipped from rhizomes of eleven plants were directly used for collection of exudates where individual sugars were determined. With the second block, collected rhizomes were placed in pots filled with soil from the original plot in November 9 , 2009. After 14 days of cultivation in the laboratory the pots were transferred into a cultivation room $\left(23^{\circ} \mathrm{C}, 12\right.$ light / 12 dark) for a period of 13 days. After this period, plant aboveground biomass height was from 9 to $69 \mathrm{~cm}$. Soil was washed from the roots with tap water, and the roots were carefully clipped from the rhizomes. In total, three samples of clipped roots, each formed from 5 poted plants were used for collection of exudates where organic acids were determined. The roots were clipped from the rhizomes.

The clipped roots were carefully washed, first using tap water and then demineralized water. Root exudates were collected in $500 \mathrm{ml}$ of $0.5 \mathrm{mM} \mathrm{CaCl}_{2}$ for a period of 2 hours in darkness at $18^{\circ} \mathrm{C}$ (Wang et al., 2006). The longer period of root exudates collection was not selected due to higher possibility of decomposition of easily degradable C compounds by microorganisms present on $M$. × Giganteus root surfaces (Aulakh et al., 2001). The medium was filtered through paper and then $0.45 \mu \mathrm{m}$ membrane filters to remove root detritus and microbial cell debris. The filtrate was assumed to contain water-soluble root exudates. Then the medium was reduced to a powder by freeze drying. The samples were kept frozen until analysis. The roots' dry matter was determined after drying at $105^{\circ} \mathrm{C}$ for 24 hours. Disadvantage of this procedure is a possibility of leakage of carbonaceous compounds from clipped roots.

Concentrations of individual carbohydrates (glucose, fructose, saccharose, arabinose) were determined using HPLC/ELSD with a ELSD (Evaporative Light Scattering Detector) operating at $70^{\circ} \mathrm{C}$, air flow 2.5 L.min ${ }^{-1}$, sensitivity 7 and a Ostion $\mathrm{Pb}^{2+}$ column $(8 \mathrm{~mm} \times 25 \mathrm{~mm}$, water as mobile phase, flow $\left.0.5 \mathrm{ml} \cdot \mathrm{min}^{-1}\right)$. Column temperature was $85^{\circ} \mathrm{C}$. Concentrations of individual organic acids (tartaric, malic, ascorbic, acetic, citric, fumaric, succinic, oxalic and propionic) were determined using HPLC with UV detector at wavelength $215 \mathrm{~nm}$, with reversed phase silica-based - TSK gel ODS-100V $4.6 \mathrm{mmID} \times 25 \mathrm{~cm}$ column, and $0.1 \%$ phosphoric acid as mobile phase, and flow $1.0 \mathrm{ml} . \mathrm{min}^{-1}$. Column temperature was $40^{\circ} \mathrm{C}$.

Rhizosphere soil (0-4mm) was taken from the Miscanthus plot in May 2010. After sieving through $5 \mathrm{~mm}$, the soil was stored at $4^{\circ} \mathrm{C}$ until the analysis. Soil properties are stated in Table I.

Carbon dioxide, evolved in the course of 24 hours from $3 \mathrm{~g}$ of wet rhizosphere soil supplied with mineral compounds and incubated at $22^{\circ} \mathrm{C}$, was measured by its absorption into $1 \mathrm{ml} 1 \mathrm{M} \mathrm{NaOH}$. Nutrients were supplied in form of $\mathrm{NH}_{4} \mathrm{Cl}, \mathrm{NaNO}_{3}, \mathrm{KCl}$ and $\mathrm{CaCl}_{2}$ in concentrations ranging from 0 to $500 \mathrm{\mu g}$ of ammonium, nitrate, potassium or calcium / g dry soil. Every sample was analyzed in 4 repetitions.

I: Selected properties of soil from cultivation of Miscanthus $\times$ Giganteus in Botanic Garden and Arboretum of Mendel University in Brno

\begin{tabular}{|c|c|c|}
\hline Soil properties & $\begin{array}{c}\text { Rhizosphere soil } \\
(0-4 \mathrm{~mm} \text { from root surface) }\end{array}$ & Bulk soil \\
\hline Clay (<0.002 mm) (\%) & 30.2 & 28.2 \\
\hline Silt (0.05-0.002 mm)(\%) & 46.3 & 45.8 \\
\hline Sand (2-0.05 mm)(\%) & 23.5 & 26.0 \\
\hline $\mathrm{pH} / \mathrm{H}_{2} \mathrm{O}$ & 7.80 & 7.99 \\
\hline $\mathrm{pH} 0.01 \mathrm{M} \mathrm{CaCl}_{2}$ & 7.57 & 7.62 \\
\hline carbon oxidable $-\mathrm{C}_{\mathrm{ox}}(\%)$ & 3.29 & 2.98 \\
\hline nitrogen total $-\mathbf{N}_{t}(\%)$ & 0.29 & 0.24 \\
\hline $\mathbf{C} / \mathbf{N}$ & 11.34 & 12.42 \\
\hline $\mathrm{CEC}_{\text {eff }}\left(\mathrm{mmol}\right.$ chem ekv $\left.\cdot \mathrm{kg}^{-1}\right)$ & 298 & 263 \\
\hline
\end{tabular}

Comments: CEC was determined according to Gillman - CSN ISO 11260, $\mathrm{C}_{\mathrm{ox}}$ spectrophotometrically after oxidation by chromsulphuric mixture ISO 14235, $N_{t}$ according to Kjeldahl (Zbíral et al., 1997). 
Statistical analysis of the data was performed through one-way ANOVA (analysis of variance) and Fisher's LSD test (least significant difference). All statistical analyses were undertaken using the Statistica 9.0 program.

\section{RESULTS}

From four measured sugars only glucose and saccharose were determined in root exudates of Miscanthus $\times$ Giganteus at the end of the summer phase of growth. They formed $20.9 \%$ (glucose) and $9.7 \%$ (saccharose) of total organic carbon of which exudation rate was on average $190.17 \mu \mathrm{g} / \mathrm{g} \mathrm{dw} / \mathrm{h}$. With regard to organic acids and their occurence in root exudates of young plants, individual organic acids were determined in concentrations ranging in the order succinic $>$ propionic $>$ citric $>$ tartaric $>$ malic $>$ oxalic $>$ ascorbic $>$ acetic $>$ fumaric (see Table II).

II: Proportion of individual organic acids in total measured organic acids of root exudates of Miscanthus $\times$ Giganteus collected in $0.5 \mathrm{mM}$ $\mathrm{CaCl}_{2}$ for period of 2 hours at $18^{\circ} \mathrm{C}$

\begin{tabular}{lc}
\hline \multicolumn{1}{c}{ Organic acid } & percent $(\%)$ \\
\hline Oxalic & 3.2 \\
Tartaric & 7.7 \\
Malic & 7.3 \\
Ascorbic & 0.8 \\
Acetic & 0.4 \\
Citric & 13.0 \\
Fumaric & 0.4 \\
Succinic & 38.9 \\
Propionic & 28.4 \\
\hline
\end{tabular}

Application of all the studied mineral compounds into rhizospheric soil increased heterotrophic respiration rate. The application of nitrate increased soil respiration rate with increasing concentration of this ion (Figure 1). Statistically significant $(\mathrm{P}<0.05)$ increase in respiration rate was found when nitrate was supplied at concentrations 100 and $500 \mu \mathrm{g} / \mathrm{g}$ dry soil. Application of ammonium did not significantly $(\mathrm{P}>0.05)$ increase respiration rate when the ion was applied in concentrations from 50 to $500 \mu \mathrm{g} / \mathrm{g}$ dry soil. Potassium appears to limit soil heterotrophic respiration and its application increased respiration rate when applied in a dose of up to $100 \mu \mathrm{g} / \mathrm{g}$ dry soil. Statistically significant $(P<0.05)$ increase was found when potassium was applied in range 50$500 \mu \mathrm{g} / \mathrm{g}$ dry soil. Increasing calcium concentration significantly $(\mathrm{P}<0.05)$ increased rhizospheric soil respiration rate in all of the samples (Figure 1).

When individual compounds addition were compared, it is possible to conclude the increase in respiration rate after application of mineral compounds in the highest amount appeared in the order nitrate $>$ calcium $>$ potassium $>$ ammonium, giving approx. 165, 99, 52 and $31 \%$ increase respectively compared to soil not amended by application of these compounds.

\section{DISCUSSION}

The rhizosphere, which is defined as the volume of soil influenced by root activity differs in many aspects from the bulk soil due to the root uptake of water and nutrients, root exudation, root respiration and the higher microbial activity. Our findings of the occurrence of individual sugars and organic acids in root exudates of Miscanthus $\times$ Giganteus and

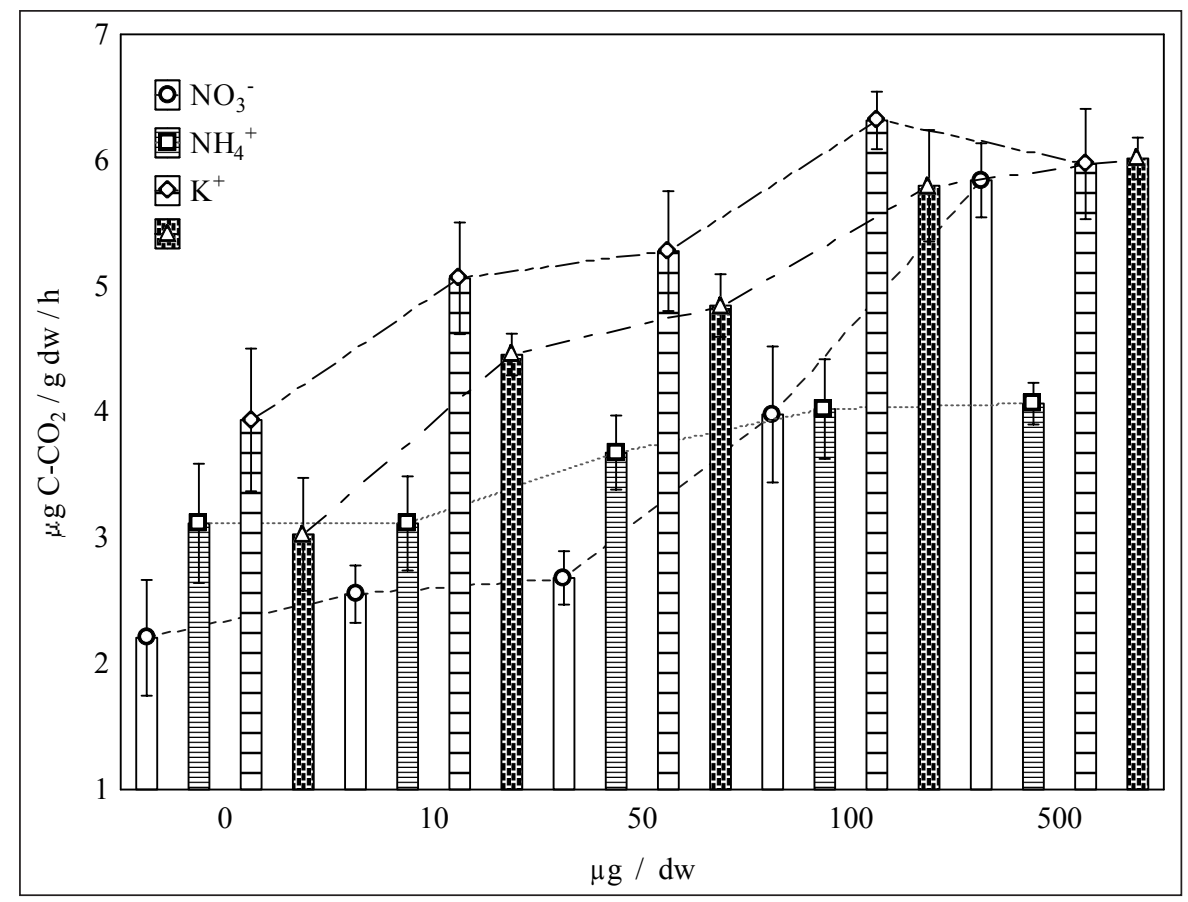

1: Respiration rate in soil from rhizosphere of Miscanthus $\times$ Giganteus (means $\pm S E, n=4$ ) 
their dominance reported in this study correspond with other studies performed on different $\mathrm{C}_{4}$-metabolism plants (Schwab et al., 1983 ; Gransee, 2001; Hütsch et al., 2002; Nardi et al., 2002, 2005).

Microbial activity in the rhizosphere may differ from bulk soil. This was proved when testing the rate of $\mathrm{CO}_{2}$ production, N-mineralization and immobilization, enzymatic activities etc. (Norton and Firestone, 1996; Pinton et al., 2007). Utilization of mineral nitrogen by microorganisms in the rhizosphere differs from bulk soil when the presence of roots reduces combined utilization of ammonium nitrogen by nitrifiers and heterotrophs (Norton and Firestone, 1996). Microbial activity in the rhizosphere may not be limited by the available carbon (Cheng et al., 1996) and lower mineral nutrient availability may limit microbial growth. McCarty et al. (1992) reported that the addition of $\mathrm{NH}_{4}{ }^{+}$or $\mathrm{NO}_{3}{ }^{-}$to glucose altered the $\mathrm{CO}_{2}$ production from the soil. This agrees with our findings that when nitrogen in mineral forms was applied to rhizospheric soil, production of $\mathrm{CO}_{2}$ was increased. Hartley et al. (2010) reported that when mineral nutrients, together with easily utilizable organic compounds such as glucose or glycine, were applied to soil dependent response may be expected. For example, an increase of $\mathrm{CO}_{2}$ production when glucose and $\mathrm{NH}_{4} \mathrm{NO}_{3}$ were applied, and also an increase when glycine and $\mathrm{NH}_{4} \mathrm{NO}_{3}$ were applied. Except for mineral nitrogen forms, other nutrients including $\mathrm{K}$ and $\mathrm{Ca}$ were proved to limit microbial respiration in the rhizosphere. Application of nutrients in our experiment could cause a change in $\mathrm{pH}$ and change in structure of soil microflora (Smiley 1974; Smiley and Cook, 1973).

As knowledge of respiration of rhizosphere microorganisms by mineral nutrients is limited more research is necessary to better understand the role of mineral nutrients in microbial activity of the rhizosphere.

\section{CONCLUSION}

Root exudates of Miscanthus $\times$ Giganteus were found to contain the following organic molecules: glucose, saccharose, succinic, propionic, citric, tartaric, malic, oxalic, ascorbic, acetic, fumaric. Respiration of soil from rhizosphere of Miscanthus $\times$ Giganteus was found to be limited by mineral nutrinets including $\mathrm{N}, \mathrm{K}$ and $\mathrm{Ca}$.

\section{SUMMARY}

The aim of this work is determine composition of sugars and organic acids in root exudates of Miscanthus $\times$ Giganteus and to determine if respiration of soil taken from rhizosphere of this plant was limited by mineral nutrients. Root exudates of this plant were collected in $0.5 \mathrm{mM} \mathrm{CaCl}$ from differently aged plants and contained two sugars including glucose and saccharose (measured in older plants at the end of summer period of growth) and several organic acids (measured in 27 days old plants) ranging in the order succinic $>$ propionic $>$ citric $>$ tartaric $>$ malic $>$ oxalic $>$ ascorbic $>$ acetic $>$ fumaric. Respiration of microorganisms in the rhizosphere of Miscanthus $\times$ Giganteus was limited by mineral nutrients including nitrate, ammonium, calcium and potassium. The increase in respiration rate after application of these mineral compounds in the highest amount (500 $\mu \mathrm{g} / \mathrm{g}$ dry soil) appeared in the order nitrate $>$ calcium > potassium > ammonium, giving approx. 165, 99, 52 and 31\% increase compared to rhizospheric soil not altered by the application of these compounds. As little is known of the limitation of rhizosphere microorganisms by mineral nutrients further research is needed to better understand these effects.

\section{SOUHRN}

Organické látky v kořenových exsudátech rostliny Miscanthus × Giganteus a limitace aktivity mikroorganismů v rhizosférní půdě této rostliny minerálními živinami

Cílem této práce bylo stanovení vybraných nízkomolekulárních organických látek v kořenových exsudátech rostliny Miscanthus $\times$ Giganteus a stanovení limitace aktivity mikroorganismů v rhizosférní půdě této rostliny minerálními živinami. Kořenové exsudáty $M$. × Giganteus byly sbírány v 0,5 mM $\mathrm{CaCl}_{2}$, přičemž rostliny v různých fázích růstu byly použity k daným účelům. Z jednotlivých cukrů byly v kořenových exsudátech $M$. × Giganteus stanoveny glukóza a sacharóza (rostliny v pozdně letní fázi růstu); organické kyseliny determinované v kořenových exsudátech mladých (27 dní) rostlin byly přítomny v následujícím pořadí koncentrací: kyselina jantarová > propionová > citronová > vinná > jablečná > štavelová > askorbová > octová > fumarová. Respirace mikroorganismů v rhizosféře byla limitována přítomností minerálních živin. Zvýšení respirace rhizosférních mikroorganismů po přídavku nejvyšších koncentrací minerálních živin (500 pg/g sušiny půdy) se projevilo v následujícím pořadí : nitráty > vápník > draslík > amonný iont, a to o 165, 99, 52 and 31\% ve srovnáni s rhizosférní půdou bez ošetření danými elementy. Vzhledem k absenci poznatků o limitaci mikroorganismů rhi- 
zosférní půdy minerálními živinami je třeba důkladněǰ̌ího a rozsáhlejšího výzkumu pro pochopení významu minerálních živin v mikrobiální aktivitě rhizosféry.

kořenové exsudáty, Miscanthus × Giganteus, organické kyseliny, cukry, respirace, rhizosféra, půda, minerální živiny

The study was supported by the project "Assesment of qualitative composition of root exudates of Miscanthus $\times$ Giganteus in different stages of growth" (IGA MENDELU 2009) and by project "Extension of current knowledge on bioavailable amino acids in soil and their utilization by soil microorganisms and plant roots"(IGA MENDELU 2010-2012).

\section{REFERENCES}

ARDUINI, I., ERCOLI, L., MARIOTTI, M., MASONI, A., 2006: Response of miscanthus to toxic cadmium applications during the period of maximum growth. Environmental and Experimental Botany, 55, 1-2: 29-40. ISSN 0098-8472.

AULAKH, M. S., WASSMANN, R., BUENO, C., KREUZWIESER, J., RENNENBERG, H., 2001: Characterization of root exudates at different growth stages of ten rice (Oryza sativa L.) cultivars. Plant Biology, 3, 2: 139-148. ISSN 1435-8603.

CHENG, W., COLEMAN, D. C., CARROLL, C. R. HOFFMAN, C. A., 1993: In situ measurement of root respiration and soluble $\mathrm{C}$ concentrations in the rhizosphere. Soil Biology and Biochemistry, 25, 9: 1189-1196. ISSN 0038-0717.

COLLURA,. S, AZAMBRE, B., FINQUENEISEL, G. ZIMNY, T., WEBER, J. V., 2006: Miscanthus $\times$ Giganteus straw and pellets as sustainable fuels. Environmental Chemistry Letters, 4: 75-78.

CURL, E. A., TRUELOVE, B., 1986: The Rhizosphere. Springer-Verlag, New York.

FORMANEK, P., REJSEK, K., VRANOVA, V., TECHER, D., LAVAL-GILLY, P., FALLA, J., 2009: Amino acids in root exudates of Miscanthus $\times$ Giganteus. 11th International Congress on Amino Acids and Proteins - Abstracts. Amino Acids, 37: 49. ISSN 0939-4451.

GRANSEE, A., 2001: Effects of root exudates on nutrient availability in the rhizosphere. In: HORST, W. J. et al. (Eds.). Plant nutrition-food security and sustainability of agro-ecosystems. Kluwer Academic, The Netherlands. p. 626-627.

GREEF, J. M., DEUTER, M., 1993: Syntaxonomy of Miscanthus $\times$ giganteus Greef et Deu. Angewandte Botanik/ Journal of Applied Botany, 67: 87-90. ISSN 0949-5460.

GREEF, J. M., SCHONDELMAIER, J., DEUTER, M., 1997: Genetic diversity of European species revealed by AFLP fingerprinting. Aspect of Applied Biology, 49: 231-235. ISSN 0265-1491.

HARTLEY, W., DICKINSON, N. M., RIBY, P., LEPP, N. W., 2009: Arsenic mobility in brownfield soils amended with green waste compost or biochar and planted with Miscanthus. Environmental Pollution, 157, 10: 2654-2662. ISSN 0269-7491.
HARTLEY, I. P., HOPKINS, D. W., SOMMERKORN, M., WOOKEY P. A., 2010: The response of organic matter mineralization to nutrient and substrate additions in sub-arctic soils. Soil Biology and Biochemistry, 42, 1: 92-100. ISSN 0038-0717.

HUISMAN, W., VENTURI, P., MOLENAAR, J., 1997: Costs of supply chains of Miscanthus giganteus. Industrial Crops and Products, 6, 3-4:353-366. ISSN 0926-6690.

HÜTSCH, B. W., AUGUSTIN, J., MERBACH, W., 2002: Plant rhizodeposition - an important source for carbon turnover in soils. Journal of Plant Nutrition and Soil Science, 165, 4: 397-407. ISSN 1436-8730.

JONES, D. L., WILLIAMSON, K. L., OWEN, A. G., 2006: Phytoremediation of landfill leachate. Waste Management, 26, 8: 825-837. ISSN 0956-053X.

KIRWAN, K., JOHNSON, R. M., JACOBS, D. K., SMITH, G. F., SHEPHERD, L., TUCKER, N., 2007: Enhancing properties of dissolution compounded Miscanthus giganteus reinforced polymer composite systems. Part 1. Improving flexural rigidity. Industrial Crop and Products, 26, 1: 14-27. ISSN 09266690.

LEWANDOWSKI, I., CLIFTON-BROWN, J. C., SCURLOCK, J. M. O., HUISMAN, W., 2000: Miscanthus: European experience with novel energy crop. Biomass and Bioenergy, 19, 4: 209-227. ISSN 0961-9534.

LEWANDOWSKI, I., SCURLOCK, J. M. O., LINDVALL, E., CHRISTOU, M., 2003a: The development and current status of perennial rhizomatous grasses as energy crops in the US and Europe, Biomass and Bioenergy, 25, 4: 335-361. ISSN 09619534.

LEWANDOWSKI, I., CLIFTON-BROWN, J. C., ANDERSSON, B., BASCH, G., CHRISTIAN, D. G., JØRGENSEN, U., JONES, M. B., RICHE, A. B., SCHWARZ, K. U., TAYEBI, K., TEIXEIRA, F., 2003b: Biofuels: Environment and harvest time affects the combustion qualities of Miscanthus genotypes. Agronomy Journal, 95, 6: 1274-1280, ISSN 0002-1962.

LINDE-LAURSEN, I., 1993: Cytogenetic analysis of Miscanthus "Giganteus", an interspecific hybrid. Hereditas, 119, 3: 297-300. ISSN 0253-9772.

MARÍN, F., SÁNCHEZ, J. L., ARAUZO, J., FUERTES, R., GONZALO, A., 2009: Semichemical pulping 
of Micanthus giganteus. Effect of pulping conditions of some pulp and paper properties. Bioresource Technology, 100, 17: 3933-3940. ISSN 0960-8524.

MCCARTY, G. W., SHOGREN, D. R., BREMNER, J. M., 1992: Regulation of urease production in soil by microbial assimilation of nitrogen. Biology and Fertility of Soils, 12, 4: 261-264. ISSN 0178-2762.

MERCKX, R., DIJKSTRA A., DEN HARTOG, A. VAN VEEN, J. A., 1987: Production of root-derived material and associated microbial growth in soil at different nutrient levels. Biology and Fertility of Soils, 5, 2: 126-132. ISSN 0178-2762.

MICHEL, R., MISCHLER, N., AZAMBRE, B., FINQUENEISEL, G., MACHNIKOWSKI, J., RUTKOWSKI, P., ZIMNY, T., WEBER, J. V., 2006: Miscanthus $\times$ Giganteus straw and pellets as sustainable fuels and raw material for activated carbon. Environmental Chemistry Letters, 4, 2: $185-$ 189.

NARDI, S., SESSI, E., PIZZEGHELLO, D., STURARO, A., RELLA, R., PARVOLI, G., 2002: Biological activity of soil organic matter mobilized by root exudates. Chemosphere, 46, 7: 1075-1081. ISSN 0045-6535.

NARDI, S., TOSONI, M., PIZZEGHELLO, D., PROVENZANO, M. R., CILENTI, A., STURARO, A., RELLA, R., VIANELLO, A., 2005: Chemical characteristics and biological activity of organic substances extracted from soils by root exudates. Soil Science Society of America Journal, 69: 20122019. ISSN 0361-5995.

NORTON, J. M., FIRESTONE, M. K., 1996: N Dynamics in the rhizosphere of Pinus ponderosa seedlings. Soil biology and biochemistry, 28, 3: 351362. ISSN 0038-0717.
PINTON, R., VARANINI, Z., NANNIPIERI, P., 2007: The rhizosphere: Biochemistry and organic substances at the soil-plant interface. CRC Press, Taylor \& Francis Group, Boca Raton.

SCHWAB, S. M., MENGE, J. A., LEONARD, R. T., 1983: Quantitative and qualitative effects of phosphorus on extracts and exudates of sudangrass roots in relation to vesicular-arbuscular mycorrhiza formation. Plant Physiology, 73, 3: 761-765. ISSN 0032-0889.

SMILEY, R. W., 1974: Rhizosphere $\mathrm{pH}$ as influenced by plants, soils, and nitrogen fertilizers. Soil science society of Amerika journal, 38: 795-799. ISSN 0361-5995.

SMILEY, R. W., COOK, R. J., 1973: Relationship between take-all of wheat and rhizosphere $\mathrm{pH}$ in soils fertilized with ammonium vs. nitrate-nitrogen. Phytopathology, 63, 7: 882-890.

STANDER, W., 1989: Determination of the highest biomass producing plant genera $\left(\mathrm{C}_{4}\right.$ Grasses $)$ of the World for temperate climates. Assessment study for the commission of the European communities, Munich, Germany.

WANG, P., BI, S., WANG, S., DING, Q., 2006: Variation of wheat root exudates under aluminium stress. Journal of Agricultural and Food Chemistry, 54, 26: 10040-10046. ISSN 0021-8561.

WHIPPS, J. M., LYNCH, J. M., 1983: Substrate flow and utilization in the rhizosphere of cereals. New Phytologist. 95, 4: 605-623. ISSN 0028-646X.

WHIPPS, J. M., LYNCH, J. M., 1990: Substrate flow in the rhizosphere. Plant and Soil, 129, 1: 1-10. ISSN 0032-079X.

ZBÍRAL, J. a kol., 1997: Analýza puid - I: jednotné pracovní postupy, ÚKZÚZ, Brno.

\section{Address}

Ing. Hana Kaňová, Ing. Valerie Vranová, Ph.D., doc. Ing. Klement Rejšek, CSc., doc. RNDr. Pavel Formánek, Ph.D., Ústav geologie a pedologie, Mendelova univerzita v Brně, Zemědělská 3, 61300 Brno, Česká republika, e-mail:xkanova0@node.mendelu.cz,vranova@mendelu.cz,kr@mendelu.cz, formanek@mendelu. cz; Joffrey Carre, University Paul Verlaine Metz, CNRS UMR 7146, IUT Thionville Yutz - Impasse A. Kastler - 57970 Yutz - France, e-mail: jo.carre@wanadoo.fr 